\title{
Article 2. Use of Terms
}

The terms defined in Article 2 of the Convention shall apply to this Protocol. In addition, for the purposes of this Protocol:

(a) "Conference of the Parties" means the Conference of the Parties to the Convention;

(b) "Convention" means the Convention on Biological Diversity;

(c) "Utilization of genetic resources" means to conduct research and development on the genetic and/or biochemical composition of genetic resources, including through the application of biotechnology as defined in Article 2 of the Convention.

(d) "Biotechnology" as defined in Article 2 of the Convention means any technological application that uses biological systems, living organisms, or derivatives thereof, to make or modify products or processes for specific use.

(e) "Derivative" means a naturally occurring biochemical compound resulting from the genetic expression or metabolism of biological or genetic resources, even if it does not contain functional units of heredity.

Overview

The most notable function of Article 2 is to introduce in international biodiversity law new definitions, ${ }^{1}$ some of which seek to delimit the scope of the Protocol ${ }^{2}$ and were negotiated as a package. ${ }^{3}$ The first key definition is 'utilization of genetic resources,' and has implications for the subject-matter scope of the Protocol and several of its operative provisions. ${ }^{4}$ This is particularly

1 VCLT Article 31(4); and comments by Villiger, "1969 Vienna Convention on the Law of Treaties," op. cit., 125. Among the additional definitions, the terms established in Article 2(a) and (b) simply allow using short references to the 'Conference of the Parties' and to the 'Convention' rather than their full official name.

2 Nagoya Protocol Article 2(c-e).

3 ENB, "Summary of the Interregional Negotiating Group on Access and Benefit-Sharing: 18-21 September 2010," unnumbered, 2-3, accessed 30 November 2013, <http://www.iisd .ca/biodiv/absing/brief/absing_briefe.html>.

4 It informs the potential scope of domestic access frameworks (Nagoya Protocol Article 6) as well as the scope of 'user measures' (see this commentary on Article 15, section 3.1) and related monitoring obligations of Parties (see this commentary on Article 17, section 2).

(C) Elisa Morgera, Elsa Tsioumani, and Matthias Buck, 2015.

This is an open access chapter distributed under the terms of the Creative Commons Attribution-Noncommercial 3.0 Unported (CC-BY-NC 3.0) License. 
significant in the absence of consistent State practice in defining/understanding the concept of genetic resources domestically or internationally. ${ }^{5}$ The term 'utilization of genetic resources,' also appears in the ABs provisions of the $\mathrm{CвD}^{6}$ to delimit the scope of potential benefits falling under the provisions of the Convention, but was left undefined. As defined in the Protocol, the term expands the interpretation of 'genetic resources,' which was defined in the Св D as 'genetic material' of actual or potential value ('any material of plant, animal or other origin containing functional units of heredity'). ${ }^{7}$ The Protocol, instead, includes not only the genetic composition, but also the 'biochemical composition' of genetic resources, ${ }^{8}$ with the aim of including 'derivatives' - another key definition introduced by the Protocol. These two new definitions, therefore, aim to include in the Protocol's scope not only genetic resources, but also material that does not contain 'functional units of heredity' (i.e. DNA), ${ }^{9}$ such as snake venoms, resins or alkaloids found in plants, or proteins. Inclusion of these definitions aimed to address one of the most challenging issues in the Protocol negotiations. But as will be discussed below, the way in which the terms are used (or not) in the Protocol raises interpretative doubts.

In addition, Article 2 clarifies that the terms defined in the CBD are to apply also to the Nagoya Protocol. ${ }^{10}$ As a result, the definitions of свD Article 2 constitute an integral part of the Nagoya Protocol. ${ }^{11}$ Among these, the ones that are clearly relevant for the interpretation of the Protocol include:

$5 \quad$ Morten W. Tvedt and Peter J. Schei, "The Term 'Genetic Resources': Flexible and Dynamic While Providing Legal Certainty?," in Oberthür and Rosendal, Global Governance of Genetic Resources, op. cit., 18 and 25-27.

$6 \quad$ СвD Articles 1 and 15(7).

7 СвD Article 2, emphasis added.

8 Glowka and Normand, “The Nagoya Protocol on Access and Benefit-sharing," op. cit., 28. It should be noted that the term 'biochemical composition of genetic resources' is vague from a scientific viewpoint, and could either refer to the biochemical composition of the gene - i.e., which can be subject to human manipulation by using biotechnology (for instance, introducing synthetic gene segments to improve gene expression) or it could refer to the biochemical composition of the organism (i.e., derivatives as products of cellular metabolism). For a scientific background, see Bruce Alberts et al., Molecular Biology of the Cell, 5th ed. (New York: Garland Science, 2012).

9 Biologically speaking, only DNA contains functional units of heredity (meaning genes), not RNA. RNA is thus included among derivatives in Figure 1, as it retains the information from functional units of heredity. We are extremely thankful to Francesca Morgera and Andrea D'Ambrogio for their inputs on scientific terminology addressed in this chapter. Any remaining errors are the authors' sole responsibility.

$10 \quad$ As clarified in the first sentence of the chapeau to Nagoya Protocol Article 2.

11 This is significant because CBD Article 2 (Use of terms) only applies 'for the purpose of [the] Convention.' 


\section{biodiversity, ${ }^{12}$ biological resources, ${ }^{13}$ biotechnology, ${ }^{14}$ country of origin, ${ }^{15}$ country providing genetic recourses, ${ }^{16}$ genetic resources, ${ }^{17}$ in situ conditions, ${ }^{18}$ sustainable use ${ }^{19}$ and technology. ${ }^{20}$}

12 Св Article 2 defines 'biological diversity' as 'the variability among living organisms from all sources including, inter alia, terrestrial, marine and other aquatic ecosystems and the ecological complexes of which they are part: this includes diversity within species, between species and of ecosystems.' The term appears in the Nagoya Protocol in the 1st, 6th, 7th, 11th, 14th, 22nd and 25th preambular recitals; as well as in Articles 1, 2(b), 4(1), 8(a), 9, 10 and 22(5)(h); and in the Annex, 2(f) and (k). The term 'biodiversity' is used in the 6th and 11th preambular recitals; and in the Annex, 1(f).

13 СвD Article 2 defines 'biological resources' as including genetic resources, organisms or parts thereof, populations, or any other biotic component of ecosystems with actual or potential use or value for humanity. The term appears in Article 2(e) of the Nagoya Protocol. сво Article 2 defines 'biotechnology' as 'any technological application that uses biological systems, living organisms, or derivatives thereof, to make or modify products or processes for specific use.' The term appears in the Nagoya Protocol in Articles 2(c-d) and in the Annex, 2(f). The adjective 'biotechnological' appears in Article 23 and in the Annex, 2(b).

15 СвD Article 2 defines 'country of origin of genetic resources' as 'the country which possesses those genetic resources in in situ conditions.' The term appears in Articles 5(1), 6(1) and 23 of the Nagoya Protocol.

16 Свр Article 2 defines 'country providing genetic resources' as 'the country supplying genetic resources collected from in situ sources, including populations of both wild and domesticated species, or taken from ex situ sources, which may or may not have originated in that country.' The term appears in the Nagoya Protocol Articles 5(1), 6(1), 23 and in the Annex, 2(b), (j) and (m). Note also that CвD Article 2 defines 'genetic material' as 'any material of plant, animal, microbial or other origin containing functional units of heredity.' The latter expression, however, is not used in the Protocol as such.

17 Свр Article 2 defines 'genetic resources' as 'genetic material of actual or potential value.' The term appears in the Nagoya Protocol 2nd, 5th, 8th, 9th, 10th, 13th, 14th, 16th, 19th, and 21st through 25th preambular recitals; in Articles 1, 2(c) and (e), 3, 4(4), 5(1-2) and (5), 6(1-2) and (3)(b) and (f), 7, 8(b-c), 9, 10, 11(1-2), 12(1-2 and 4) and 12(3)(a) and (c); 13(1) $(\mathrm{a}-\mathrm{b})$ and 13(4), 14(3)(c), 15(1), 16(1), 17(1)(a-b), (3) and (4)(f), 18(1), 21, 22(4)(d) and (5) (j), 23 and in the Annex, (2)(b), (e), (f), (j) and (m).

18 Свр Article 2 defines 'in situ conditions' as 'conditions where genetic resources exist within ecosystems and natural habitats, and in the case of domesticated or cultivated species, in the surroundings where they have developed their distinctive properties.' The term appears in Article 11(1) of the Nagoya Protocol.

19 СвD Article 2 defines 'sustainable use' as 'the use of components of biological diversity in a way and at a rate that does not lead to the long-term decline of biological diversity, thereby maintaining its potential to meet the needs and aspirations of present and future generations.' The term appears in the Nagoya Protocol in the 6th, 7th, 22nd and 25th preambular recitals; in Articles 1, 8(a), 9, 10, 22(5)(h) and in the Annex, 1(f) and 2(k).

СвD Article 2 defines 'technology' as including biotechnology. The term appears in the Nagoya Protocol in the 5th preambular recital; in Articles 2(c-d), 22(5)(g) and 23, and in the Annex, at 2(f) and (g). 
It should be further noted that the Nagoya Protocol does not define 'utilization of traditional knowledge associated with genetic resources,' although the expression is used in its operative provisions. ${ }^{21}$ This gap is particularly noteworthy as no other international treaty has referred to this concept or more generally to 'traditional knowledge associated with genetic resources.'22

The following sections will focus on explaining the definition of utilization of genetic resources, by breaking it down into its components, and linking it to the definition of derivatives. The implicit exclusion of biological resources ${ }^{23}$ (as opposed to genetic resources) used as commodities in trade from the scope of the Protocol, and the lack of definition of utilization of traditional knowledge will be also briefly discussed.

\section{Utilization of Genetic Resources}

The term first appeared, without being defined, in the СвD, both in its objectives and in its provision devoted to access to genetic resources, when referring to benefit-sharing arising from the 'utilization of genetic resources. ${ }^{24}$ To fill this gap, the Nagoya Protocol negotiators initially considered a list of activities falling under the term 'utilization, ${ }^{25}$ but eventually decided in favor of a general definition that could allow for covering rapidly developing technologies and uses, potentially unknown at the time of negotiation. ${ }^{26}$ In particular, the

21 E.g. Nagoya Protocol Articles 3, 5(5), 10, $12(2-4), 16(1)$ and 18(1). The term appears also in the preamble and in the Annex to the Protocol.

22 Tvedt and Schei, “The Term 'Genetic Resources,'” op. cit., 24-25. See also Introduction to this commentary, section 3.

23 СвD Article 2.

24 СвD Articles 1 and 15(7).

25 See non-exhaustive list of activities in the CвD Working Group on ABs, "Report of the meeting of the Group of Legal and Technical Experts on Concepts, Terms, Working Definitions and Sectoral Approaches" (12 December 2008) un Doc UneP/CbD/ WG-ABS/7/2, paragraphs 7-8, including: genetic modification, biosynthesis, breeding and selection, propagation and cultivation of genetic resources in the form received, conservation, characterisation and evaluation, and production of compounds naturally occurring in genetic material. The final text of Article 2 includes only one specific activity, namely the application of biotechnology.

26 See Peter J. Schei and Morten W. Tvedt, The Concept of "Genetic Resources" in the Convention on Biological Diversity and How It Relates to a Functional International Regime on Access and Benefit-Sharing (Lysaker: Fridthof Nansen Institute, 2010), circulated in the ABS negotiations as UNEP/CBD/WG-ABs/9/INF/1. 
Protocol hinges the definition on the intent ${ }^{27}$ underlying 'utilization of genetic resources' (by reference to 'research and development'), as well as the material on which the conduct focuses ('on the genetic and/or biochemical composition of genetic resources').

\section{$2.1 \quad$ The Intent}

The terms 'research' and 'development' are not defined in the Nagoya Protocol or in the СвD. ${ }^{28}$ Based on their ordinary meaning, ${ }^{29}$ 'research' means the investigation or experimentation aimed at the discovery and interpretation of facts. ${ }^{30}$ In the context of the Protocol and when it is used in combination with 'development,' it refers to the two closely related processes intended to create new products and new forms of old products through technological innovation. ${ }^{31}$ This may include all types of systematic work on the genetic or biochemical composition of genetic resources aimed to discover potentially interesting properties and to devise practical applications of such discoveries.

In practice, different sectors (e.g., agriculture, cosmetics and pharmaceuticals) have different approaches to research and development. ${ }^{32}$ For the purposes of the Protocol, however, it does not matter where research and development take place - in the provider country or in another jurisdiction - and by whom it is carried out - by a public or private individual or entity. Arguably, while the Protocol applies to all types of research, whether it is characterized as

27 Based on legislative experience in Australia: see Burton, "Implementation of the Nagoya Protocol in JusCanz Countries," op. cit., 301-302.

28 СвD Articles 17(7) and 25(2).

29 VCLT Article 31(1) states that 'the ordinary meaning [is] to be given to the terms of the treaty in their context and in the light of its object and purpose.'

30 'Research' in Oxford Dictionaries Online, accessed 10 October 2013, <http://oxforddictio naries.com/definition/english/research >: 'A search or investigation undertaken to discover facts and reach new conclusions by the critical study of a subject or by a course of scientific inquiry.'

31 'Research and Development' in Encyclopcedia Britannica Online, accessed 10 October 2013, <www.britannica.com/EBchecked/topic/499010/research-and-development >: 'two intimately related processes by which new products and new forms of old products are brought into being through technological innovation.'

СвD Working Group on ABS, "Report of the expert meeting on definitions," UNEP/CBD/ WG-ABs/7/2, paragraph 17; свр Secretariat, "Access and Benefit-Sharing in Practice: Trends in Partnerships Across Sectors," свD Technical Series No. 38 (Montreal: СвD Secretariat, 2008); Institute for European Environmental Policy, "Study to analyse legal and economic aspects of implementing the Nagoya Protocol on ABs in the European Union" (2010), accessed 30 October 2013, <http://ec.europa.eu/environment/biodiversity/international/abs/pdf/ABS\%20FINAL\%20REPORT.pdf >, Annex 3 
'fundamental' research without commercial objective or whether it explicitly aims at developing commercial products, ${ }^{33}$ it draws a distinction between research carried out for commercial purposes and research for non-commercial purposes to which special considerations apply. ${ }^{34}$ The Protocol itself acknowledges, however, that difficulties arise in practice in determining the presence of the commercial intent in specific research activities at a specific point in time, ${ }^{35}$ particularly when a commercial purpose may arise at successive stages of research, either because the original researcher changed his/ her intent ${ }^{36}$ or where another researcher with commercial purposes uses the results of non-commercial research. ${ }^{37}$

\section{$2.2 \quad$ The Material}

Utilization relates to 'the genetic and/or biochemical composition of genetic resources'. This formulation was the result of a long-standing debate among СвD Parties and ABs stakeholders on the exact understanding of the term 'genetic resources' under the Convention. This debate revolved around whether

33 Ibid., paragraphs 17 and 43-45. See also свD Group of Legal and Technical Experts on Concepts, Terms, Working Definitions and Sectoral Approaches, "Concepts, terms, working definitions and sectoral approaches relating to the international regime on access and benefit-sharing, Submission from the International Workshop on the topic of 'access and benefit-sharing in non-commercial biodiversity research' " (29 November 2008) UN Doc UNEP/CBD/ABS/GTLE/1/INF/2, paragraph 5 .

34 Nagoya Protocol Article 8(a). See this commentary on Article 8, section 2.

35 Nagoya Protocol Article 8(a) underscores the need to address a change of intent in the context of non-commercial research.

36 This could be the case where access to a plant was sought for non-commercial purposes by a university team of researchers from a user country in accordance with the national legislation of the provider country, but later one member of the research team continues doing research on the plant in another company leading to a highly successful (and maybe patented) product: Elisa Morgera, Matthias Buck and Elsa Tsioumani, "Introduction," in Morgera, Buck and Tsioumani, 2010 Nagoya Protocol on Access and Benefit-Sharing in Perspective, op. cit., 1, 5 .

37 This could be the following case: a university researcher requests prior informed consent and enters into mutually agreed terms for academic, non-commercial research on a plant. He publishes the results of his research in a scientific journal without mentioning the country of origin of the samples, the limitations on the use, or the existence of a benefitsharing agreement. Two years later, another scientist undertaking applied research in the food industry reads the article and acquires a sample of the African plant from a botanical garden in his country: the research on the plant sample leads to a highly successful (and maybe patented) product. Morgera, Buck and Tsioumani, "Introduction," op. cit., 6. 
the term referred only to material containing functional units of heredity (i.e. DNA) or more broadly gene expressions such as RNA, proteins and enzymes (which do not contain functional units of heredity per se, but retain information from them) and any naturally occurring biochemical compounds resulting from cellular metabolism (i.e., resins, essential oils, and fragrances). ${ }^{38}$ The latter does not contain functional units of heredity or information from them, ${ }^{39}$ and therefore can only be synthesized if the compounds are extracted directly from the organism.

While the reference to 'biochemical composition of genetic resources' in Article 2(c) does not clarify the material that is the object of utilization selfevidently, the combined reading of this provision with the other new definitions provided in the Protocol, in particular that of derivatives (explained below), leads to the conclusion that all of the above is covered by the Protocol. ${ }^{40}$

\subsubsection{Derivatives}

Derivative is a term used in the CвD in relation to the definition of 'biotechnology'11 and in the Bonn Guidelines as an item to be potentially addressed in relation to benefit-sharing as part of the information required for obtaining $\mathrm{PIC}^{42}$ and when establishing мат. ${ }^{43}$ Neither instrument, however, define the term. During the negotiations of the Protocol, there was no common understanding of what the term 'derivative' (i.e., material not containing functional units of heredity) may include. It could refer to the results of cellular metabolism. ${ }^{44}$ It could further be understood as information on genetic resources. But it could also refer to any result of human activity utilizing a genetic resource, such as a chemical compound extracted from an organism and purified by human activity, gene segments isolated by human manipulation of genetic material, synthetic gene segments produced by human manipulation or a synthetic

\footnotetext{
38 See Singh Nijar and Pei Fern, Nagoya A Bs Protocol, op. cit., 113-114.

39 See Figure 1.

40 This is the only interpretation that would give effect to the entirety of Article 2 (on the effectiveness principle for treaty interpretation, see Introduction to this commentary, section 5). See also Burton, "Implementation of the Nagoya Protocol in Juscanz Countries," op. cit., 302-303.

41 СвD Article 2.

42 Bonn Guidelines, paragraph 36(l).

43 Bonn Guidelines, paragraph 44(i).

44 СвD Working Group on ABS, "Report of the expert meeting on definitions," UNEP/CBD/ WG-ABS/7/2, paragraphs 9-10, refers to 'organism's metabolism' in that regard.
} 
analogue of a gene segment inspired by a natural gene. ${ }^{45}$ Developing countries sought to include specific reference to derivatives within the Protocol general provisions, arguing that this is where the actual or potential value of genetic resources lies primarily as the main interest of modern biosciences. ${ }^{46}$ Accordingly, failure to specifically mention derivatives in the Protocol would have significantly narrowed the scope for benefit-sharing and would not have served the ultimate fulfillment of neither the Protocol's nor the СвD objectives. Some industrialized countries, in contrast, argued that the CBD only refers to 'genetic resources' (genetic material containing functional units of heredity). ${ }^{47}$ Behind this argument were concerns about legal and economic costs arising from an international ABS instrument that would introduce the need for PIC and benefit-sharing requirements to a broad spectrum of industrial activities. These countries thus rather preferred to leave it to MAT to clarify how derivatives are understood on a case-by-case basis by the individual parties to a specific ABS transaction and set out specific benefit-sharing modalities in that contractual context. ${ }^{48}$

As this divergence of views continued, the compromise reached was to eliminate all references to the term 'derivative' in the operational provisions of the Protocol with the understanding that the term 'utilization of genetic resources' (or its alternative forms - e.g., 'utilized', 'use', 'used') would include the notion of derivatives. ${ }^{49}$ This led to the puzzling inclusion of the term 'derivatives' only in

45 Drawing from свD Working Group on ABs, "Report of the expert meeting on definitions," UNEP/CBD/WG-ABS/7/2, paragraphs 9-10.

46 Matthias Buck and Claire Hamilton, "The Nagoya Protocol on Access to Genetic Resources and Benefit-sharing Arising from Their Utilization to the Convention on Biological Diversity," Review of European Community and International Environmental Law 20 (2011): 47, 56 .

47 Making reference to Св Article 15. Note however that not all developed countries shared this view. The 2005 Australian legislation, for instance, defined access as the taking of a biological resource for the purpose of research and development on its genetic and biochemical compounds. See EPBC Regulations 2000 Part 8A.03, accessed 14 February 2014, <www.comlaw.gov.au/Details/F2005L03473>. We are grateful to Geoff Burton for drawing our attention to this.

48 ENB 9/527, "Summary of the Resumed Ninth Meeting of the Working Group on ABs," 6.

49 Ibid., 16. See also Ryo Kohsaka, The Negotiating History of the Nagoya Protocol on ABs: Perspective from Japan (2012), accessed 30 November 2013, <www.ipaj.org/english_jour nal/pdf/9-1_Kohsaka.pdf>, 61. The compromise was developed at the meeting of the Interregional Negotiating Group on Access and Benefit-sharing in September 2010 and then again by the Japanese сор Presidency during свр сор 10. See свD Working Group on ABS, "Draft Protocol on Access to Genetic Resources and the Fair and Equitable Sharing of Benefits Arising from their Utilization to the Convention on Biological Diversity" in 
the Protocol provision on 'definitions', although the term as such is not referred to anywhere else in the Protocol. Its relevance, however, to the interpretation of 'utilization of genetic resources' (or its alternative forms) throughout the Protocol operative text can be argued on two grounds. First, there is an indirect link between 'utilization' and 'derivatives' via an explicit reference to 'including through the application of biotechnology' in the definition of 'utilization.' That is, the definition of 'biotechnology' in the Protocol - which uses the wording of the $\mathrm{CBD}^{50}$ - refers to 'any technological application that uses ... derivatives [of living organisms] to make or modify products or processes for specific use.' Therefore, utilization implicitly refers also to research and development through the application of biotechnology on derivatives. In this connection, it should be emphasized that the CBD notion of biotechnology is broader than 'modern biotechnology' that is exclusively understood as genetic engineering, ${ }^{51}$ and therefore allows the Protocol to cover a series of biological technologies involving materials not containing functional units of heredity. ${ }^{52}$ Second, the definition of 'utilization' makes reference to the 'biochemical composition of

"Report of the meeting of the Interregional Negotiating Group," (21 September 2010) UN Doc UneP/CвD/WG-ABs/9/ING/1, Annex (hereinafter, Montreal II draft), draft article 2(c); and ENB, "Summary of the Interregional Negotiating Group on Access and BenefitSharing: 18-21 September 2010", 2-3. This terminology is deployed in Nagoya Protocol Article 5(1): benefits arising from the 'utilization of genetic resources;' Article 6(1): access to genetic resources 'for their utilization;' Article 15(1): 'genetic resources utilized;' and Article 17(1): 'utilization of genetic resources'. The compromise also included: referring to 'subsequent applications and commercialization' not in the definition of 'utilization' but in Article 5; and providing for the issuance of a permit 'at the time of access' (Nagoya Protocol Article 6.3(e)). See Buck and Hamilton, "The Nagoya Protocol," op. cit., 56.

50 The definition of 'biotechnology' in Nagoya Protocol Article 2(d) is a verbatim reproduction of the definition of the term in СвD Article 2. Thus, its inclusion in the Nagoya Protocol is not strictly necessary, since CBD definitions also apply to the Nagoya Protocol. Its inclusion in Article 2 can only be explained by the fact that it creates an explicit, albeit indirect, link between 'derivatives' and 'utilization of genetic resources.' Beyond its implicit relevance whenever 'utilization of genetic resources' appears in other operational provisions of the Protocol, the term 'biotechnology' appears only once in the Protocol text, in the Annex listing examples of monetary and non-monetary benefits which Parties may consider for inclusion in MAT (see Nagoya Protocol Article 5(4) and this commentary on Article 5, section 6).

$5^{1} \quad$ That is, as opposed to the restrictive understanding of biotechnology under the Biosafety Protocol. We are thankful to Riccardo Pavoni for drawing our attention to this point.

See CвD Working Group on ABS, "Report of the expert meeting on definitions," UNEP/ СвD/WG-ABs/7/2, paragraph 19. 
genetic resources' 53 which arguably relates to the reference to 'biochemical compounds' in the definition of 'derivatives', as it is only the latter that provides the necessary elements to circumscribe this otherwise vague concept. ${ }^{54}$ The operational value of the definition of 'derivatives' for the Protocol, therefore, is to further clarify the definition of 'utilization of genetic resources': it serves to articulate that naturally occurring biochemical compounds resulting from genetic expression or cellular metabolism, and not containing DNA, can be the focus of utilization for the purposes of research and development.

While this interpretation of the role of the definition of derivatives in the Protocol appears as the only one to give effect to the entirety of Article 2, the unfortunate drafting may raise doubts in interpreters and as a consequence lead to variations in national legislation implementing the Protocol. ${ }^{55}$ When developing domestic ABS frameworks, national legislators would be well advised to establish that they apply not only to genetic resources collected in situ in their territory but also to compounds extracted or resulting from such resources. Guidance from the Protocol's governing body ${ }^{56}$ would be beneficial in that regard.

International guidance could also address the case of 'isolated derivatives' i.e. derivatives acquired and utilized without physical access to genetic resources, such as those already extracted and isolated from their natural environment and available ex situ - which are arguably covered by the definition of 'utilization of genetic resources' and thus by the Protocol. ${ }^{57}$ For example:

53 Singh Nijar, “An Asian Developing Country's View," op. cit., 250.

54 See $\mathrm{fn} .8$ above on the vagueness of the notion from a scientific perspective. Note also that the WIPO negotiating text includes a bracketed definition of derivatives that reiterates the wording of Nagoya Protocol Article 2(e): wiPo General Assembly, "Matters concerning the IGC" wo/GA/43/14, Annex A, paragraph 2.

55 See divergence of views between the European Parliament and the Council of the European Union (EU) as to the need for explicit inclusion of derivatives in proposed EU regulation implementing the Nagoya Protocol in the Eu in "Amendments adopted by the European Parliament on 12 September 2013 on the proposal for a regulation of the European Parliament and of the Council on Access to Genetic Resources and the Fair and Equitable Sharing of Benefits Arising from their Utilization in the Union ( C7-0322/2012 - 2012/0278(COD)," accessed 30 November 2013, <www.europarl.europa.eu/ sides/getDoc.do?type=TA\&reference=P7-TA-2013-0373\&language=EN\&ring=A7-20130263>, amendments 38, 39 and 43.

56 Nagoya Protocol Article 26(4): see this commentary on Article 26, section 2.

57 Singh Nijar "An Asian Developing Country's View," op. cit., 250; see also Greiber et al., Explanatory Guide, op. cit., 67. This implies that the definition of 'utilization' may lead to situations where there can be benefit-sharing without access in situ (see this commentary on Article 5, section 2). Indeed, at least in the case of the EU, it appears that most commercial users of genetic resources source new material from ex situ collections, including 
a plant produces a resin. Such resin is collected, its biochemical compounds are extracted and isolated in the laboratory of the local university. A foreign researcher obtains access only to the isolated biochemical compounds but not to the resin, nor to the plant that produced the resin. As domestic ABs frameworks may cover isolated derivatives differently in provider and user countries, such discrepancy may eventually play out in the cooperation between specific provider and user countries in the context of the compliance provisions of the Protocol. 58

Finally, an issue that is not explicitly addressed by the Protocol and remains to be clarified relates to bioinformatics, i.e. the application of computer science and information technology to the field of biology, molecular biology in particular. By applying information technology, mankind can further expand and develop the understanding of biological processes. In practice, bioinformatics is a way of realizing the value in the genetic material without the need for access to the biological sources where it was originally found. ${ }^{59}$ Thus, it remains unclear whether the definition of 'utilization' covers, and thus the Protocol may apply to, exchanges of information concerning derivatives (but no longer exchanges of derivatives as such). However, on the basis of the definition of 'derivative,' it has been observed that 'functional' could refer both to the genetic structure per se and to the information encapsulated in the DNA sequence that can be screened and transferred electronically and become

from collections in countries of origin. See European Commission, Impact Assessment (Part I) accompanying the Commission proposal for an $\mathrm{EU}$ regulation on access to genetic resources and benefit-sharing, $\operatorname{swD}(2012) 292$ final (4 October 2012), 15. In addition, Schei and Tvedt argue that the interpretation of the definition of 'genetic resources' and their uses needs to be dynamic as regards new technologies, in order to meet the overall objectives of the benefit-sharing objective and obligation in the CBD. See Schei and Tvedt, Concept of Genetic Resources, op. cit., 17.

$5^{8}$ See this commentary on Article 15. Practical questions related to ensuring benefit-sharing and enforceability are expected to be addressed on a case-by-case basis, see Singh Nijar "An Asian Developing Country's View," op. cit., 254. In particular, triggering of the Protocol's compliance provisions would be facilitated by national legislation in both user and provider countries providing for documentation requirements or standards to identify the source or origin of the isolated derivative in question, and thus a clear chain of information connecting the genetic resource to the compound used in research and development and requiring due diligence by researchers in that regard. See Buck and Hamilton, "The Nagoya Protocol," op. cit., 53. Impossibility to trace the country of origin and obtain PIC would lead to a situation specifically foreseen by the Protocol as a consideration for the possible creation of a multilateral benefit-sharing mechanism: see this commentary on Article 10, section 2.2.

See Schei and Tvedt, Concept of Genetic Resources, op. cit., 15. 
functional in a new, digital form." ${ }^{10}$ In that light, it has been argued that 'the biological origin rather than the biological form [of the information] matters' for falling under the definition of utilization of genetic resources. ${ }^{61}$ Another argument could be made on the basis of the definition of 'utilization of genetic resources,' as research and development on the genetic and/or biochemical 'composition' could be interpreted to include the information this composition is transcribed to. In effect, the definitions of the Protocol appear capable to be interpreted dynamically in the light of relevant technological developments, ${ }^{62}$ with a view to including any new technique that 'in fact realizes the value of functional units of heredity'63 and avoiding that the Protocol become obsolete in a few years' time. That being said, such broad interpretation may create challenges for the architecture of the Protocol, which has been conceived without specific consideration of bioinformatics.

While guidance by the Protocol's governing body on this issue will be needed, the issue has already arisen in the context of the International Treaty on Plant Genetic Resources for Food and Agriculture (ITPGRFA): ${ }^{64}$ in 2013, Secretary Shakeel Bhatti highlighted the 'increasing trend for the information and knowledge content of genetic material to be extracted, processed and exchanged in its own right, detached from the physical exchange of the plant genetic material' and called on Parties to widen the focus of the ITPGRFA provisions with the potential to address the non-material values of genetic resources. ${ }^{65}$

6o Tvedt and Schei, “The Term 'Genetic Resources,'” op. cit., 20-21.

61 Ibid.

62 Ibid., 21.

63 Ibid., 29. On the question, see also Joseph Henry Vogel et al., "The Economics of Information, Studiously Ignored in the Nagoya Protocol on Access to Genetic Resources and Benefit Sharing," Law, Environment and Development Journal 7 (2011): 52.

64 International Treaty on Plant Genetic Resources for Food and Agriculture (Rome, 3 November 2001, in force 29 June 2004) 2400 unTs 303.

65 See Report of the Secretary of the International Treaty on Plant Genetic Resources on Food and Agriculture, Appendix I in the Report of the Fifth Session of the Governing Body of the International Treaty on Plant Genetic Resources on Food and Agriculture, (2013) FAO Doc Iт/G B-5/13/Report, 4-5. 


\section{Gene expression}

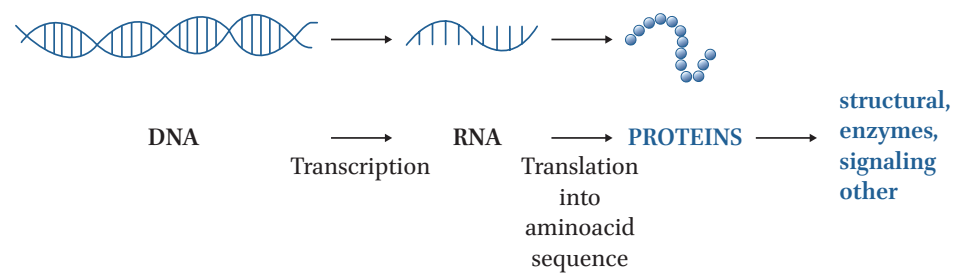

\section{Genetics resources}

Biological organism (animal, plant or microbe)

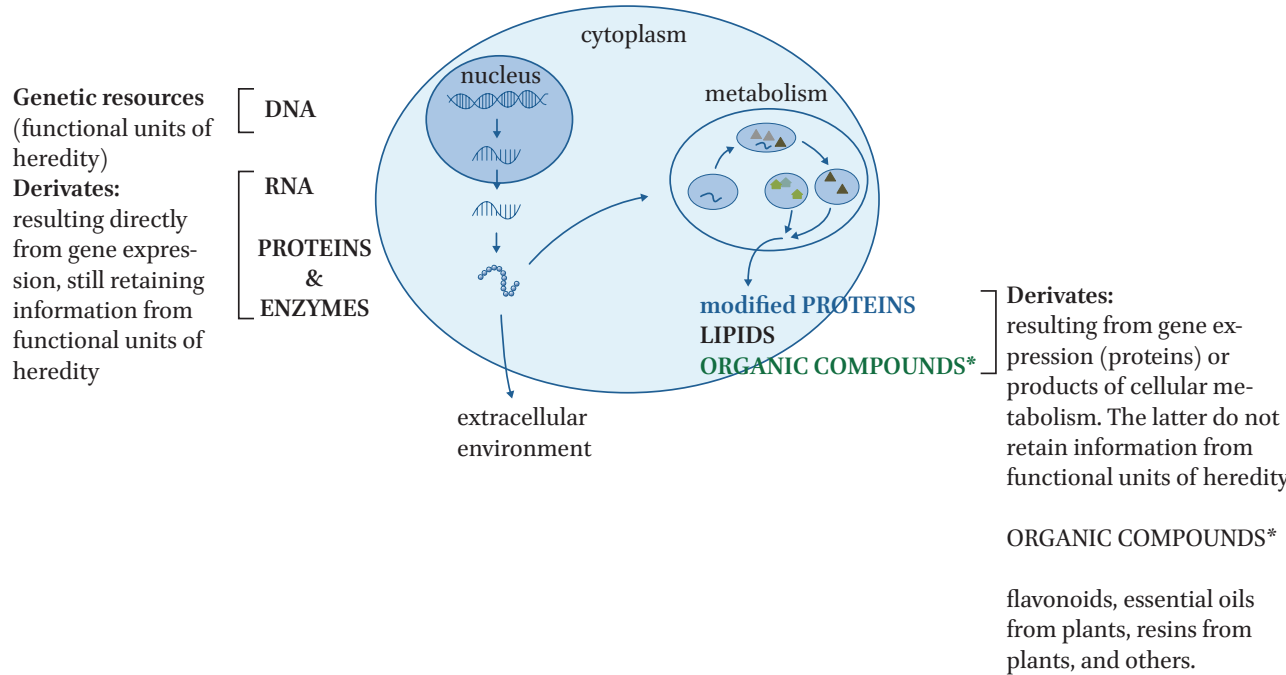

FIGURE 1 Figure developed by Francesca Morgera on the basis of Bruce Alberts et al., Molecular Biology of the Cell, 4 th ed (New York: Garland Science; 2002). 


\subsubsection{Commodities in Trade}

Since the beginning of the negotiations of the Nagoya Protocol, questions have arisen about whether it would affect international trade in commodities (agricultural and forest products, cut flowers, herbal teas, etc.). ${ }^{66}$ This was based on some СвD Parties' understanding that ABS could also apply to biological resources (as opposed to genetic resources), an understanding which was reflected in certain pieces of national legislation. ${ }^{67}$ The rationale behind this expansive approach is to prevent a loophole: that access to biological resources for consumptive uses can lead to the use of their genetic or biochemical composition for research and development purposes, without respecting the Protocol requirements on PIC and benefit-sharing at the time of access to the resources (i.e., when they entered international trade). ${ }^{68}$ Other свр Parties, particularly from the industrialized world, were concerned about an excessively broad approach subjecting international trade in commodities to ABS rules and its potential ( $\mathrm{ab}$ ) use by some Parties with a view to establishing nontariff barriers to trade. ${ }^{69}$

As emerged shortly after the conclusion of the Nagoya Protocol, the use of imported commodities for research and development purposes is not just a matter of academic speculation. In May 2010, Nestlé, the world's largest food company, faced allegations of biopiracy after it applied for five patents involving medicinal uses of two plants found and commonly used in South Africa, rooibos and honeybush, and commonly traded internationally as herbal teas,

66 In response, some Parties submitted proposals of operational text at the seventh meeting of the Working Group on ABs that explicitly excluded 'commodities in trade' from the scope of the regime: see CвD, "Compilation of submissions by Parties, governments, international organisations, indigenous and local communities and relevant stakeholders in respect of the main components of the international regime on access and benefitsharing listed in Decision IX/12, Annex I" (2 February 2009) un Doc UneP/CbD/ WG-ABS/7/INF/1, paragraphs 24 and 43.

67 See for example Costa Rica's Biodiversity Law No. 7788, 1998, analysed in Jorge Cabrera Medaglia, "The Implementation of the Nagoya Protocol in Latin America and the Caribbean: Challenges and Opportunities," in Morgera, Buck and Tsioumani, 2010 Nagoya Protocol on Access and Benefit-Sharing in Perspective, op. cit., 331, 343-347. See also Australia, Environment Protection and Biodiversity Conservation Regulations, No. 181,2000 , where 'access to biological resources' means 'the taking of biological resources of native species for research and development on any genetic resources, or biochemical compounds, comprising or contained in the biological resources...'

68 СвD Working Group on ABs, "Report of the expert meeting on definitions," UNEP/СвD/ WG-ABs/7/2, paragraph 6 .

69 Pavoni, “Nagoya Protocol and wTo Law," op. cit., 197-199. 
without having negotiated the relevant permit with the South African government. Two non-governmental organizations (NGOs) alleged that the patent applications were in violation of the South African Biodiversity Act, which implements the CBD provisions on ABS in South Africa. According to it, a company needs a permit from the South African government to do research with commercial intent on, or patent the use of, genetic resources occurring in South Africa. Such a permit can only be obtained if a benefit-sharing agreement has been negotiated. ${ }^{70}$ Nestlé maintained that any biopiracy claims are baseless since it neither sourced the plants in South Africa nor did research on them there. Rooibos and honeybush extracts and material were provided by South African suppliers to two Nestlé research facilities in Switzerland and France, which used them for basic research on active ingredients. ${ }^{71}$ The company added that the patents were filed to protect research results, but there was no plan for their commercial use. The controversy illustrates the need for additional clarity with regard to the use for research of plants exported as commodities, to address the change of intent and the time when the benefitsharing obligation arises. ${ }^{72}$

While the final text of the Protocol does not include any explicit reference to commodities, ${ }^{73}$ Parties are nonetheless broadly required to take measures, under the compliance provisions of the Protocol, to avoid the circumvention of the general provisions on PIC and benefit-sharing that could potentially arise in the context of the international commodity trade. In view of the Protocol's objective and based on an effectiveness-driven interpretation, these provisions ${ }^{74}$ should be interpreted as implying that Parties prevent genetic material and biochemical compounds originated from biological resources imported as commodities from being subjected to research and development without

$70 \quad$ "Rooibos robbery: Nestlé accused of biopirating South African genetic resources," Berne Declaration (27 May 2010), accessed 30 November 2013 <www.evb.ch/en/f25001910. html>.

71 "Lessons from the 'rooibos robbery," International Centre for Trade and Sustainable Development, Bridges vol. 14 no. 4 (10 December 2010), accessed 30 November 2013, $<$ http://ictsd.org/i/news/bridges/98765/>.

72 Ibid.

73 An explicit exclusion was considered during the negotiations but was eventually abandoned: Свр Working Group on ABs, "Draft Protocol on Access to Genetic Resources and the Fair and Equitable Sharing of Benefits Arising from their Utilization to the Convention on Biological Diversity" in "Report of the Third Part of the Ninth Meeting of the Ad Hoc Open-Ended Working Group on Access and Benefit-sharing” (17 October 2010) UN Doc UNEP/CBD/COP/10/5/Add.5, Annex (hereinafter, Nagoya Draft), draft article 3(d).

74 See this commentary on Article 15. 
seeking PIC and establishing MAT according to the domestic ABS framework of the Party where the 'commodity' was acquired.

\section{$3 \quad$ Utilization of Traditional Knowledge}

In the absence of an explicit definition, utilization of traditional knowledge needs to be understood by combining different elements of the Protocol. It can be interpreted along similar lines to the definition of 'utilization of genetic resources.' In other words, as traditional knowledge under the Protocol would serve as lead information for the utilization of genetic resources, ${ }^{75}$ it can be understood as hinging on the same intent (research and development) as in the case of genetic resources. In addition, this lacuna in the Protocol should be seen as part of a general approach to avoiding definitions or specifications for several other expressions used in relation to traditional knowledge. Therefore, the interpretation of utilization of traditional knowledge needs to allow for flexibility at the national and sub-national level, given the wide range of contexts within which any traditional knowledge-related concepts and provisions apply in practice. ${ }^{76}$ Furthermore, as any other traditional knowledge-related term or provision in the Protocol 'utilization of traditional knowledge' needs to be understood in light of relevant international human rights law, ${ }^{77}$ as well as taking into account indigenous and local communities' customary laws, protocols and procedures. ${ }^{78}$

75 СвD Working Group on Article 8(j), "Report of the sixth meeting," UNEP/CBD/COP/10/2, 36. See discussion in the Introduction to this commentary, section 3.

76 See свр Working Group on Aвs, "Report of the expert meeting on traditional knowledge," $\mathrm{UNEP} / \mathrm{CBD} / \mathrm{WG}-\mathrm{ABS} / 8 / 2$, paragraph 10.

77 See discussion in Introduction to this commentary, section 4.

78 In light of the cross-cutting provision of Nagoya Protocol Article 12(1): see this commentary on Article 12, section 2. 